Lingua Rima: Jurnal Pendidikan Program Studi Bahasa dan Sastra Indonesia

Vol. 9 No. 1 Juli 2020

\title{
GERAKAN LITERASI GENERASI MILENIAL MELALUI MEDIA SOSIAL
}

\author{
Ira Anisa Purawinangun ${ }^{1}$, Maulana Yusuf ${ }^{2}$ \\ Universitas Muhammadiyah Tangerang \\ irapurawinangun@gmail.com ${ }^{1}$ \\ My.maul24@gmail.com²
}

\begin{abstract}
ABSTRAK
Media sosial adalah sebuah jembatan komunikasi baik antar personal maupun antar badan atau lembaga dengan menggunakan fasilitas internet. Saat ini penggunaan media sosial merupakan sebuah fenomena yang lumrah, semua orang dapat menggunakan sosial mediakhususnya generasi milenial. Penggunaan media sosial tak luput dari konten yang berisi pendidikan, karya sastra, seni, olahraga, berita, dan lain sebagainya. Hal tersebut turut diupayakan sebagai wujud digalakanya gerakan literasi bagi generasi milenial. Penelitian yang digunakan adalah penelitian kualitatif dengan metode deskripsi analisis berupa, wawancara yang meliputi penggunaan media sosial, minat baca generasi milenial dalam media sosial, dan perolehan informasi dari media sosial. Target dalam wawancara ini adalah siswa-siswi SMK dan mahasiswa. Hasil daripada penelitian ini dapat dijadikan acuan dari tingkat efisiensi penggunaan media sosial terhadap tingkat literasi generasi milenial.
\end{abstract}

Kata kunci: Media sosial, literasi, generasi milenial.

\section{A. PENDAhuluan}

Seiring dengan perkembangan zaman yang semakin maju, perkembagan teknologi dan informasi serta kominukasi pun ikut melaju dengan cepat. Saat ini, perkembangan teknologi informasi dan komunikasi sangatlah pesat. Perkembangan media yang masif terus mengalami revolusi, semua terkoneksi atau terhubung dengan internet, sebagai contoh pengiriman surat, saat ini tidaklah hanya menggunakan jasa pengiriman kantor pos, tetapi sudah dapat menggunakan fasilitas surel dalam jaringan internet.Semua orang dapat menikmatinya dan lebih efisien dalam penggunaan waktu.

Perkembangan internet tidak hanya sampai di sana, tetapi juga telah merambah kepada dunia pendidikan. Kini dunia pendidikan virtual tengah digalakan. Seelain itu, perkembangan daripada internet telah menghadirkan sebuah buku elektronik yang dapat diunduh oleh pelajar dan atau mahasiswa yang memudahkannya untuk meningkatkan minat baca yang "kekinian" dalam digitalisasi. 
Lingua Rima: Jurnal Pendidikan Program Studi Bahasa dan Sastra Indonesia

Vol. 9 No. 1 Juli 2020

Dalam digitalisasi, tak lepas pula media sosial sebagai media pendidikan, khususnya literasi.Media sosial adalah sebuah jembatan komunikasi baik antar personal maupun antar badan atau lembaga dengan menggunakan fasilitas internet.Saat ini penggunaan media sosial merupakan sebuah fenomena yang lumrah, semua orang dapat meggunakan sosial media khususnya generasi milenial.Penggunaan media sosial tak luput dari konten yang berisi pendidikan, karya sastra, seni, olahraga, berita, dan lain sebagainya.Hal tersebut turut diupayakan sebagai wujud digalakanya gerakan literasi bagi generasi milenial.Media sosial merupakan salah satu dari sistem komunikasi.Pesatnya perkembangan media sosial seperti sekarang karena semua orang bisa memiliki media sendiri. Jika Anda memiliki media tradisional seperti televisi, radio, atau koran dibutuhkan modal yang besar dan tenaga kerja yang banyak, maka lain halnya dengan media.

Media sosial yang mudah untuk diakses siapa pun, mulai anak-anak, remaja hingga dewasa.Penggunaan media sosial terhadap generasi milenial, kini berdampak kepada tingkat literasi mereka.Pencarian berita terkini, kegemaran, kesehatan dan kebugaran, perwatan diri, hingga digitalisasi karya sastra, semua terdapat di dalam media sosial. Pemanfaatan teknologi, khususnya internet saat ini merupakan sebuah hal yang positif, kemajuan ilmu pengetahuan dan teknologi dunia mengharuskan sumber daya manusianya untuk "melek teknologi" khususnya bagi para generasi milenial.

Literasi tak lepas kaitannya dengan sebuah teks atau pun wacana.Literasi merupakan keterampilan dalam menulis dan membaca dalam aktivitas mengolah informasi dan pengetahuan untuk kecakapan hidup. Di era saat ini, literasi tidak hanya dilakukan dengan cara membaca buku fisik, namun telah merambah kepada digitalisasi.Dewasa ini pun, banyak penulis muda berkarya melalui media virtual yang dapat menjangkau segala penjuru (jangkauan) khususnya generasi milenial yang aktif di dalamnya.Efisiensi waktu dan biaya menjadi salah satu alasan para gerenasi muda untuk membaca di media sosial tersebut.

Dalam penelitian ini, titik berat masalahnya adalahsejauh mana tingkat literasi generasi milenial dalam media sosial dalam penggunaannya sebagai media untuk mengakses atau mendapatkan berita-berita terkini, mendapatkan ilmu pengetahuan dan pemahaman yang baru daripada konten yang diikuti dalam akun media sosial yang dimilikinya.Dari berbagai latar belakang yang telah dikemukakan, peneliti tertarik melakukan penelitian dengan judul Peranan Media Sosial dalam Upaya Gerakan Literasi Generasi Milenial. 
Lingua Rima: Jurnal Pendidikan Program Studi Bahasa dan Sastra Indonesia

Vol. 9 No. 1 Juli 2020

\section{B. LANDASAN TEORI}

\section{Literasi dan Generasi Milenial}

Literasi tak lepas kaitannya dengan sebuah teks atau pun wacana. Literasi merupakan keterampilan dalam menulis dan membaca dalam aktivitas mengolah informasi dan pengetahuan untuk kecakapan hidup. Di era saat ini, literasi tidak hanya dilakukan dengan cara membaca buku fisik, namun telah merambah kepada digitalisasi.

Dewasa ini, banyak penulis muda berkarya melalui media virtual yang dapat menjangkau segala penjuru (jangkauan) khususnya generasi milenial yang aktif di dalamnya. Efisiensi waktu dan biaya menjadi salah satu alasan para gerenasi muda untuk membaca di media sosial tersebut.

\section{Penggunaan Media Sosial terhadap Literasi Generasi Milenial}

Salah satu media yang kini paling digemari oleh generasi milenial, yakni media sosial. Mereka dapat menyampaikan dan mendapatkan informasi dan pengetahuan dengan waktu yang relatif singkat. Media sosial merupakan salah satu perkembangan dari adanya internet, salah satunya ialah perkembangan media pendidikan, perkembangan media pendidikan dalam internet sendiri memiliki karakteristik, sebagaimana yang dikemukakan Rina dalam Purawinangun (2019: 86) karakteristik media pembelajaran berbasis internet ada empat, yaitu internet merupakan jaringan yang luas, internet sebagai media komunikasi interaktif, internet sebagai pusat informasi, dan internet berbiaya, sedangkan Arsyad (2013: 195) mengemukakan bahwa "implementasi dunia internet telah banyak diterapkan di seluruh dunia, ada konsep e-learning atau konsep pembelajaran jarak jauh, di mana antara guru/dosen dan murid/mahasiswa bisa melakukan kegiatan pembelajaran di luar sekolah/kampus".

Penggunaan media sosial terhadap generasi milenial, kini berdampak kepada tingkat literasi mereka. Pencarian berita terkini, kegemaran, kesehatan dan kebugaran, perwatan diri, hingga digitalisasi karya sastra, semua terdapat di dalam media sosial. Pemanfaatan teknologi, khususnya internet saat ini merupakan sebuah hal yang positif, kemajuan ilmu pengetahuan dan teknologi dunia mengharuskan sumber daya manusianya untuk "melek teknologi" khususnya bagi para generasi milenial.Media sosial pun mempunyai karakteristiknya sendiri, sebagaimana yang dikemukakan Musser dan O'Reilly dalam Fatmawati, yakni sebagai berikut:

1. Memungkinkan pengguna web untuk melakukan lebih dari sekedar menelusur informasi. 
Lingua Rima: Jurnal Pendidikan Program Studi Bahasa dan Sastra Indonesia

Vol. 9 No. 1 Juli 2020

2. Memungkinkan pengguna melakukan eksekusi langsungb dari browser dan kemudian mengintrol data pada platform media sosial.

3. Pengguna dapat menambah nilai konten yang diakses. Hal ini arena media sosial bersifat user friendly sehingga tidak perlu membutuhkan pengetahuan khusus untuk menggunakannya.

4. Perangkat media sosial yang desentralisasi tanpa adanya system kontrol.

5. Transparan dan menggunakan standar teknologi yang tumbuh pesat menjadi ekosistem terbuka, membangun aplikasi untuk membangun data terbuka dan menggunakan komponen.

6. Muncul media sosial tidak tergantung pada aplikasi pada struktur yang telah ditetapkan sebelumnya.

\section{METODE PENELITIAN}

Penelitian inimenggunakan adalah penelitian kualitatif, penelitian kualitatif adalah penelitian yang bersifat deskriptif dan cenderung menggunakan analisis dengan metode deskripsi analisis, deskripsi analisis adalah suatu metode yang berfungsi untuk mendeskripsikan atau memberi gambaran terhadap objek yang diteliti melalui data atau sampel yang telah terkumpul (Sugiono: 2009: 29). Data tersebut beruapa pembagian questioner atau angket dan wawancara dengan target (sasran) generasi milenial yang masih bersekolah di tingkat Sekolah Menengah Kejuruan (SMK), mahasiswa, dan pekerja "generasi milenial”.Penelitian dimulai pada tanggal 19 September hingga 8 Oktober 2019. Dalam penelitian ini, peneliti memilih lokasi penelitian yang berbeda, letaknya di Kecamatan Ciledug, Kecamatan Karang Tengah (Kota Tangerang), Kecamatan Teluknagadan Kecamatan Sepatan (Kabupaten Tangerang).

\section{HASIL PENELITIAN DAN PEMBAHASAN}

Dari penelitian ini, didapatkan hasil dan temuan daripada generasi milenial yang diwawancarai dan atau yang telah mengisi angket (questioner). 
Lingua Rima: Jurnal Pendidikan Program Studi Bahasa dan Sastra Indonesia Vol. 9 No. 1 Juli 2020

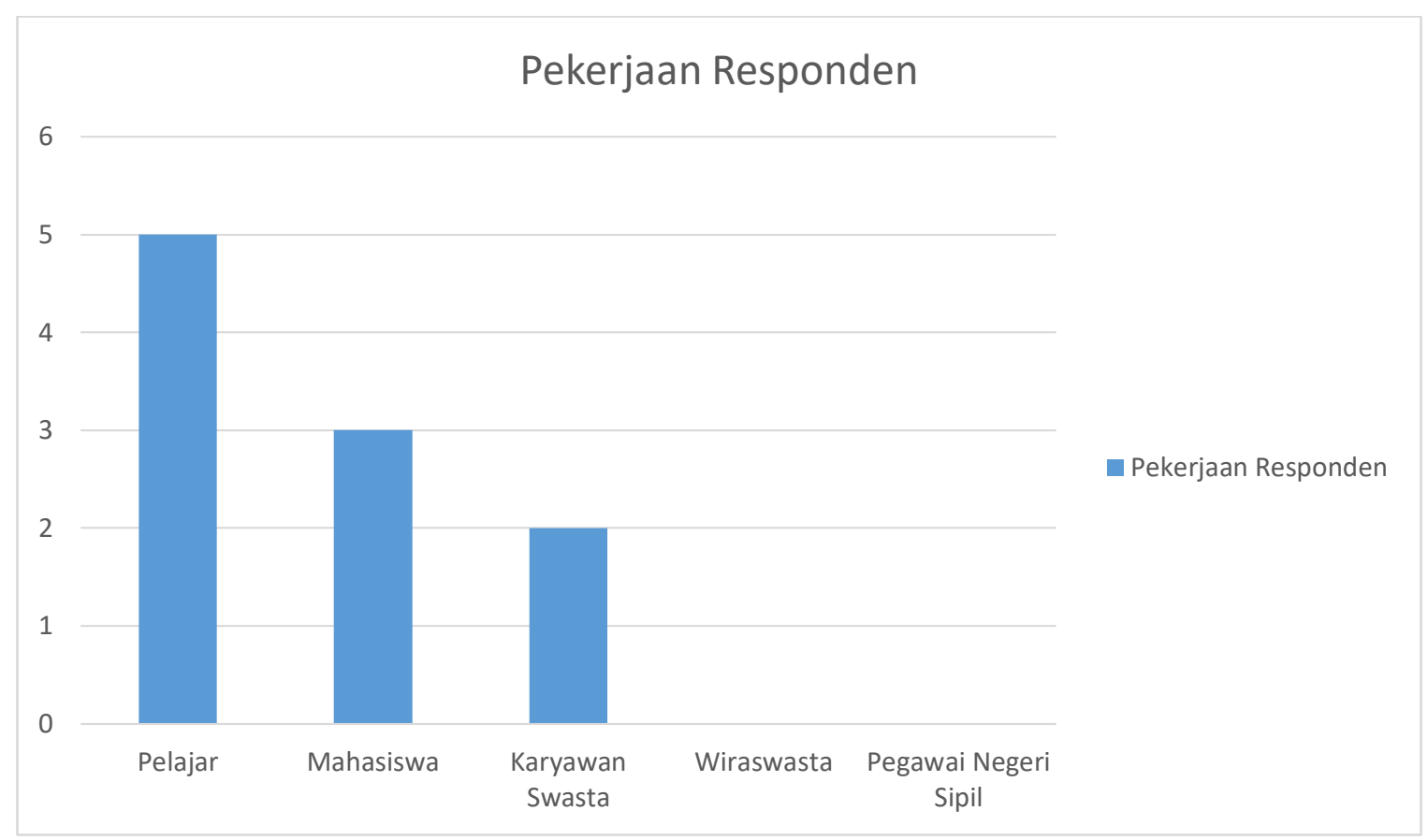

Sampel responden diambil secara acak dari setiap daerah. Dari sampel di atas, terdapat sepuluh orang responden, di antaranya limaorang pelajar, tiga orang mahasiswa, dan dua orang karyawan swasta. Antusiasme pelajar terhadap penggunaan media sosial nampak tinggi.

Selanjutnya yakni kepemilikan media sosial para generasi milenial, peneliti mendapatkan hasil temuan, sebagai berikut:

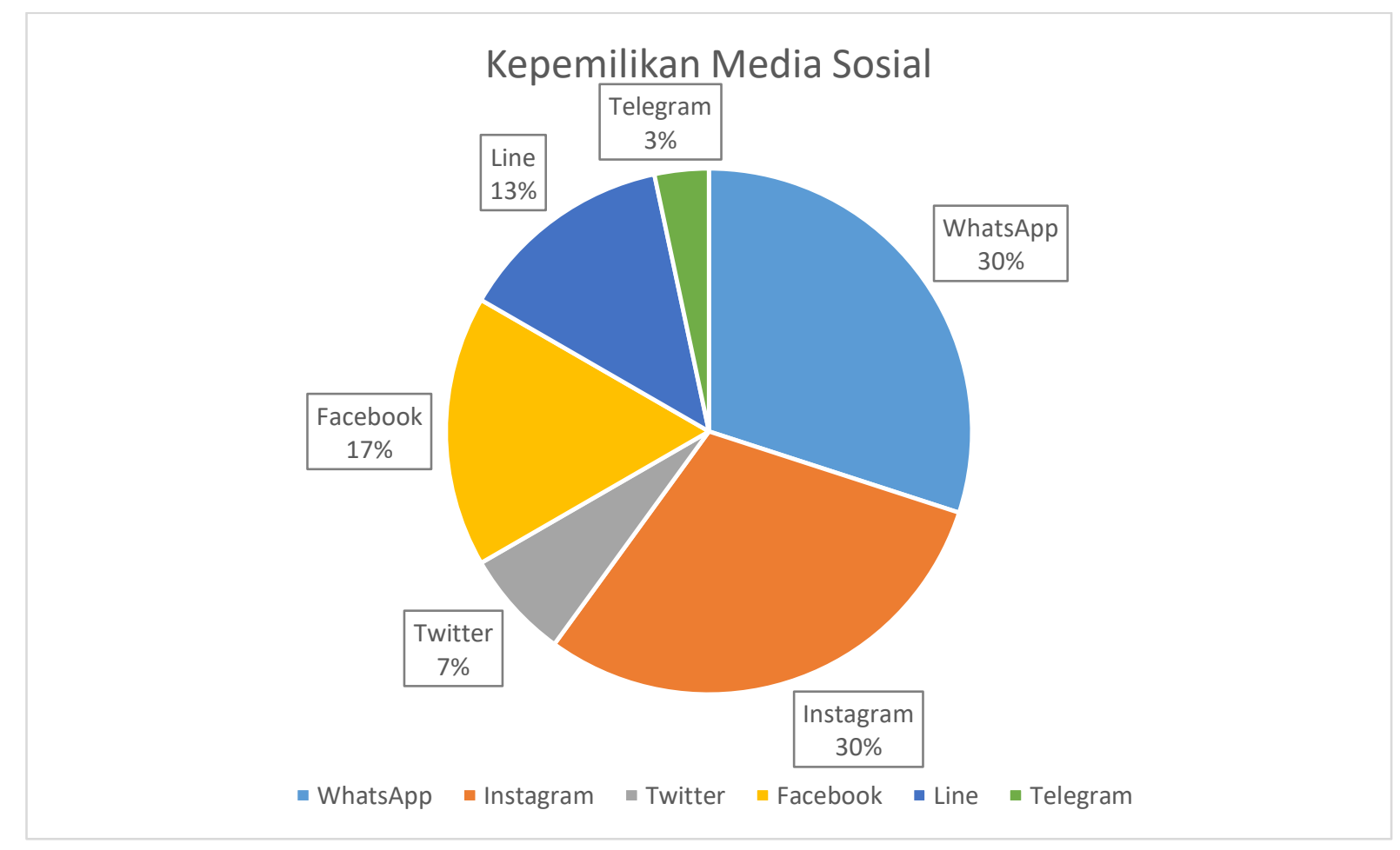


Lingua Rima: Jurnal Pendidikan Program Studi Bahasa dan Sastra Indonesia

Vol. 9 No. 1 Juli 2020

Hasil dari penelitian ini, didapatkan pengguna media sosial WhatsApp dan Instagram yang paling banyak dimiliki oleh generasi milenial.

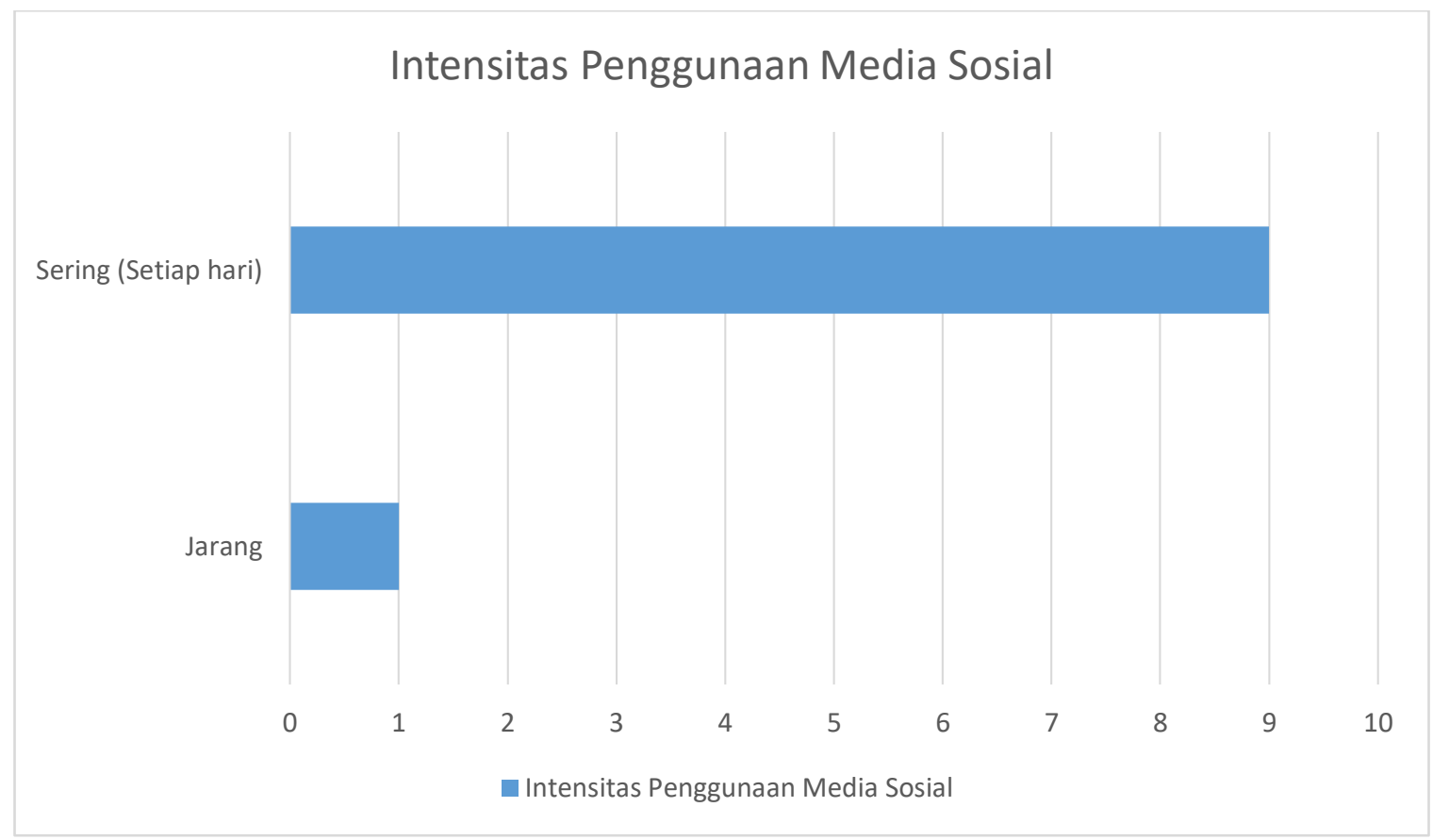

Dari gambar grafik di atas, generasi milenial mengaku jika ia menggunakan sosial media dalam kehidupan sehari-hari untuk berbagai keperluan (kepentingan).

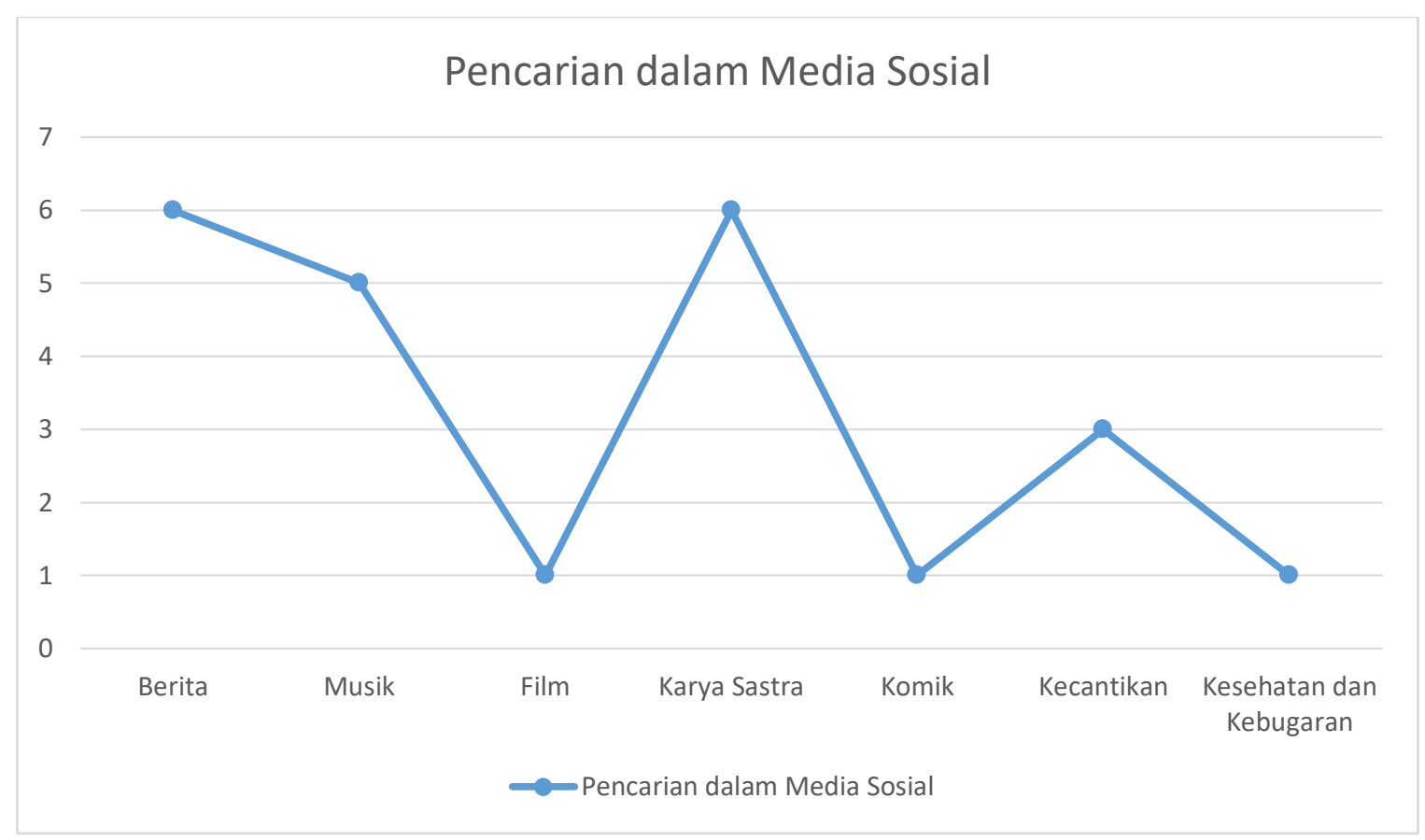

Dari diagram di atas, terlihat generasi milenial mengakses media sosial untuk mengakses berita, musik, film, karya sastra, komik, kecantikan, dan kesehatan serta kebugaran. Hal tersebut 
dapat disimpulkan, ketertarikan generasi milenial terhadap penggunaan media sosial dalam mencari informasi terkini dan seputar karya sastra, gaya hidup, dan hiburan.

Generasi milenial mendapatkan banyak informasi melalui informasi terkini dari sosial media, kecepatan dan keakuratan berita merupakan hal yang dicari oleh generasi milenial yang kritis. Sebagaimana respons atas pertanyaan saat wawancara.

\begin{tabular}{|l|l|}
\hline \multicolumn{2}{|c|}{ Informasi apa yang Anda dapatkan setelah mengakses media sosial? } \\
\hline R.1 & Ilmu baru dan informasi terkini \\
\hline R.2 & Info yang saya belum tahu menjadi tahu \\
\hline R.3 & Banyak \\
\hline R.4 & Berita terkini \\
\hline R.5 & Informasi terkini yang sedang banyak diperbincangkan oleh banyak orang \\
\hline R.6 & Novel, karya sastra puisi,komik terbaru \\
\hline
\end{tabular}

Ket: Huruf "R" diartikan sebagai "Respons"

Dapat disimpulan dari respons di atas, bahwa generasi milenial mencari informasi seputar berita dan informasi terkini dan untuk hiburan berupa karya sastra seperti novel, puisi, serta komik.

\begin{tabular}{|l|l|}
\hline \multicolumn{2}{|c|}{ Opini Anda berdasarkan konten yang disukai } \\
\hline R.1 & Ipteks adalah sebuah pilar dalam peradaban sebuah bangsa \\
\hline R.2 & Keren \\
\hline R.3 & Bagus \\
\hline R.4 & $\begin{array}{l}\text { Minat dan kegemaran dalam diri saya, konten yang saya sukai sebagai } \\
\text { motvasi, hiburan, dan sebagai sumber informasi }\end{array}$ \\
\hline R.5 & $\begin{array}{l}\text { Novel dan karya sastra, Saya menyukainya karena banyak bahasa (kata) } \\
\text { yang mungkin jarang diketahui orang, dan komik yang memunculkan } \\
\text { kreativitas menggambar dan mengangkat sebuah cerita, sehingga } \\
\text { memberikan sebuah kesan yang berbeda saat membacanya. }\end{array}$ \\
\hline
\end{tabular}

Ket: Huruf "R" diartikan sebagai "Respons"

Selanjutnya adalah respons responden terhadap sumber untuk mendapatkan sebuah berita terkini, sebagai berikut: 


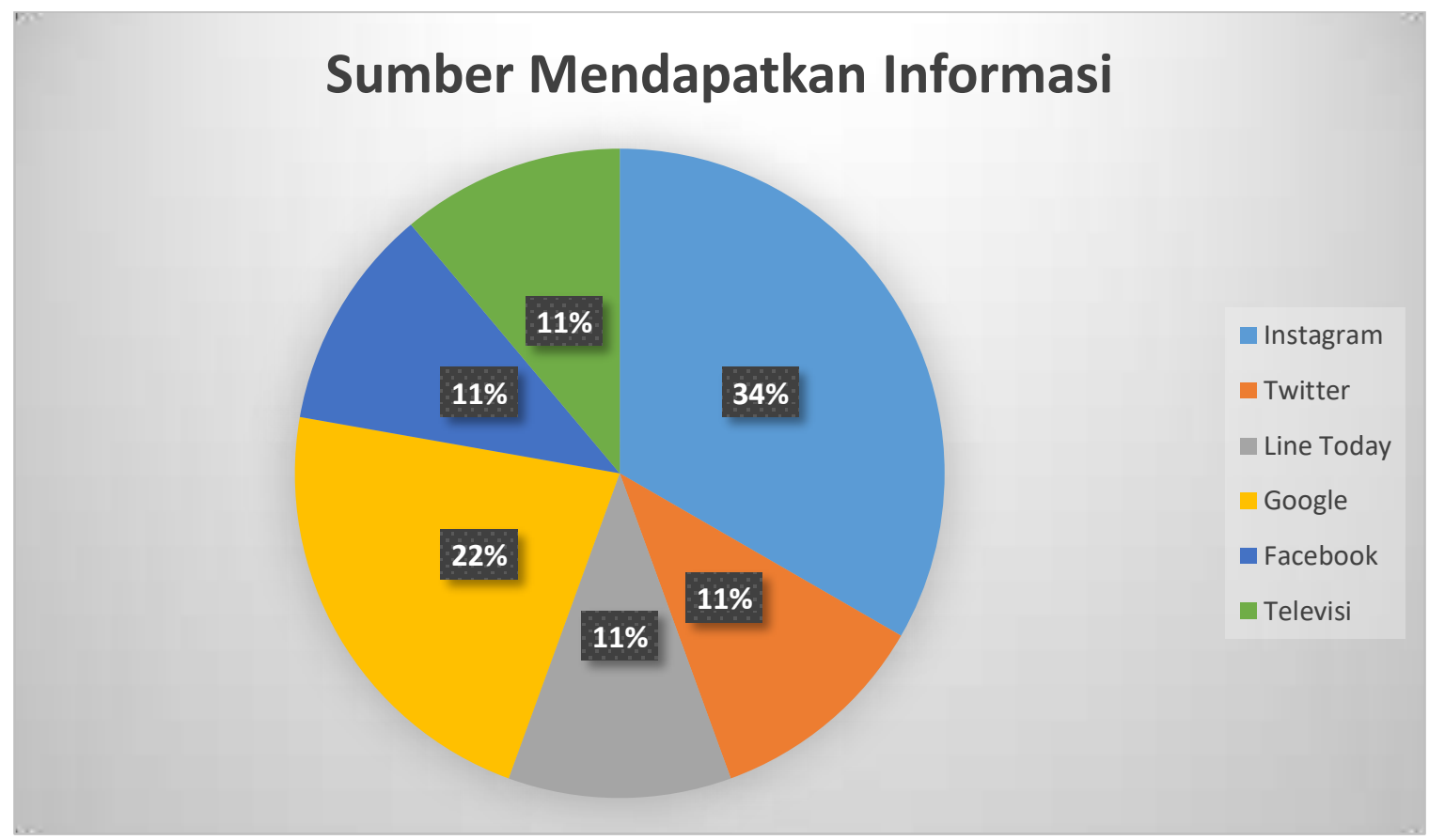

Dari grafik di atas, generasi milenial lebih tertarik terhadap penggunaan media sosial terhadap pencarian informasi.

\section{Media yang lebih disukai}

12

10

2

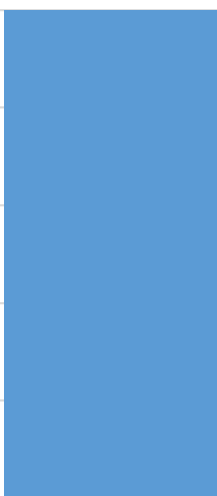

Media berbasis dalam jaringan

Media berbasis cetak

Media yang lebih disukai

Dari grafik di atas, generasi milenial lebih tertarik terhadap penggunaan media berbasis dalam jaringan daripada media berbasis cetak terhadap pencarian informasi.

\section{E. SIMPULAN}


Dari penelitian di atas, dapat disimpulkan secara keseluruhan bahwa generasi milenial memilih menggunakan media sosial untuk mengakses berita dan informasi terkini yang belum tertuang di dalam media cetak, kecepatan dan ketepatan informasi yang diperoleh melalui siaran resmi dari badan atau lembaga bersangkutan yang kredibel, membuat media sosial unggul di kalangan generasi milenial untuk mengakses berita, kesehatan, gaya hidup, hingga hiburan.

\section{F. DAFTAR PUSTAKA}

Arsyad, Azhar. 2013. Media Pembelajaran. Jakarta: PT RajaGrafindo Persada.

Fatmawati, Endang, 2017. "Dampak Media Sosial Terhadap Perpustakaan" Libraria - Jurnal Perpustakaan. STAIN Kudus. Vol (5) No. 1 Tahun 2017 Hal 1-28. (http://journal.stainkudus.ac.id/index.php/Libraria/article/view/2250/pdf).

Purawinangun, Ira Anisa. 2019. Media Pendidikan. Yogyakarta: Penerbit Samudra Biru

Wiridjati, Wikan dan Renny Risqiani Roesman. 2018. "Fenomena Penggunaan Media Sosial dan Pengaruh Teman Sebaya pada Generasi Milenial Milenial terhadap Keputusan Pembelian" Jurnal Manajemen dan Pemasaran Jasa. Universitas Trisakti. Vol (11) No. 2, Tahun 2018 Hal 275-290. (http://doi.org/10.25105/jmpj.v11i2.2950). 